\title{
OPTIMIZATION OF IGNITION ZONE OF ADVANCED FAST REACTOR, WORKING IN NUCLEAR BURNING WAVE MODE
}

\author{
S. P. Fomin ${ }^{1,2}$, A.I. Kirdin ${ }^{1}$, M.S. Malovytsia ${ }^{2 *}$ V. V.Pilipenko ${ }^{1}$, N. F. Shul'ga ${ }^{1,2}$ \\ ${ }^{1}$ Akhiezer Institute for Theoretical Physics, \\ National Science Center "Kharkiv Institute of Physics and Technology", 61108, Kharkiv, Ukraine; \\ ${ }^{2}$ V.N. Karazin Kharkiv National University, 61077, Kharkiv, Ukraine
}

(Received August 2, 2018)

\begin{abstract}
This article deals with the problem of optimizing composition and structure of the ignition zone of the fast reactor operating in the self-sustaining mode of nuclear burning wave with the purpose of its smooth start-up and reducing fissile material amount in initial assembly. The cylindrical homogeneous reactor with the ignition zone placed in the center or near the cylinder end is considered. The analysis has been performed basing on solving the non-stationary neutron diffusion equation together with the fuel burn-up equations and the equations of nuclear kinetics for precursor nuclei of delayed neutrons, with using the radial buckling approximation. An optimized structure of the ignition zone has been proposed, which ensures a smooth transition of the reactor to the self-sustaining nuclear burning wave mode, avoiding an excessive energy release, which is observed when using a simplified scheme of ignition zone. Comparison of the startup variants with the ignition zone at the cylinder end and at its center shows the benefits of the second one.
\end{abstract}

PACS: 28.41.Bm,44.05.+e,47.11.-j

\section{INTRODUCTION}

The prospective nuclear burning wave (NBW) reactor can work automatically in the critical state without external control, which makes it attractive as a concept for the future generation reactors. This feature is caused by the specific negative feedback mechanism inherent in the fast reactor (FR) of this type, which provides its "intrinsic safety". Another important feature of this FR is possibility to use natural or even depleted uranium and thorium as a fuel. L. P. Feoktistov was the first who considered this problem within a simple model in his works $[1,2]$, where he obtained feasibility criterion for this NBW mode. Further research of this concept was developed by Yu. Goldin [3], Van Dam [4], E. Teller [5], H. Sekimoto [6] and other.

Different properties of the NBW mode were studied in previous publications of the authors [7-12]. The performed numerical calculations showed feasibility of such FR with metal fuel of the U-Pu and mixed Th-U-Pu cycles with quite realistic isotope compositions of the reactor under some conditions analogous to those pointed in $[1,2]$. The previous research allowed us to develop a mathematical model describing non-stationary processes during starting the NBW in the initial assembly of the cylindrical FR with homogeneous zones and its propagation in the axial direction. The model is based on the deter- ministic approach with numerically solving the nonstationary diffusion equation of neutron transport in the FR medium along with the fuel-component burnup equations as well as the equations of nuclear kinetics for the precursors of delayed neutrons with using effective multi-group nuclear cross sections and constants.

A case of simplified scheme of the FR startup was used in the works [7-12], where the NBW propagation in the breeding zone filled with fertile isotopes is initiated by an external neutron flux, which irradiates the end face of the cylindrical FR, where an ignition zone, i.e. the initial active zone with fuel enriched with plutonium, is placed. It is worth mentioning that in the works [7-10], the ignition zone had a uniform distribution of components. In this scheme, a substantial disadvantage is an excessive rise in the energy release in the ignition zone during the NBW reactor startup in comparison with steady state mode of the NBW propagation. This is due to lack of fission products at the initial stage of the reactor operation. In fact, the accumulation of a large number of fission products that only absorb neutrons and reduce the rate of chain reactions, is a stabilizing factor at the stage of the steady-state NRW regime. This caused a problem of searching for possibilities of initiating the NBW mode in the FR with acceptable values of the energy release density and total power production without an extreme increase of the neutron flux

*Corresponding author E-mail address: jcm2027@gmail.com 
in the ignition zone. Further study of the FR with the NBW mode proved the suppression of initial power growth to be possible, which can be done by using the ignition zone with a special structure $[6,11,12]$.

In the scenario considered in the present paper, the NBW reactor operation is initiated by the ignition zone placed in the center of FR. It is very desirable to be able to start the self-sustaining chain reaction in the ignition zone by a low intensity neutron source, which could be easily implemented in practice. Along with this, there remains the problem of preventing excessive rise in the neutron flux and energy release and removing other considerable variations in the FR power during the startup of NBW mode.

Possibilities of optimizing the NBW initiation in the FR with metal Th-U-Pu fuel will be discussed below in this paper. In the considered scenario of the FR start-up we use the initial active zone (ignition zone) placed in the center of the reactor, which initiates the NBW propagation along the axis of cylindrical reactor in two directions from this ignition zone. The initial FR parameters will be chosen to have an optimized ignition zone which would provide satisfactory values of parameters of the FR operation.

\section{CALCULATION MODEL}

The model discussed in this paper is for the NBW reactor that has cylindrical form and uses the metal
Th-U-Pu fuel. The structure of this reactor is shown in Fig. 1. The NBW is propagating in the reactor along the cylinder axis (the axial direction $O z$ ). Unlike our previous works, the FR considered in the present paper is symmetrical relative to the central plane $(Z=0)$ and is composed of three zones of two kinds. On the left and right sides of the cylinder, there are two identical homogenous breeding zones, which occupy most of the reactor core volume and are filled with the fertile fuel materials ${ }^{238} U+{ }^{232} T h$. The initial active ignition zone is placed at the center of the reactor and is filled with the fertile fuel ${ }^{238} U+{ }^{232} T h$ enriched with plutonium with the common isotope composition: ${ }^{239} \mathrm{Pu}:{ }^{240} \mathrm{Pu}:{ }^{241} \mathrm{Pu}$ : ${ }^{242} P u=0.70: 0.22: 0.05: 0.03$ (e.g. [13]). The computer simulation was performed with taking into account the constructional material $\mathrm{Fe}$ and coolant (eutectic $\mathrm{Pb}-\mathrm{Bi}$ alloy) in the ignition and breeding zones, with using realistic values of volume fractions for these materials. The initial active zone is schematically shown as the homogenous cylinder section in Fig.1 where $-L_{i g}<z<L_{i g}$ corresponds to the simple ignition zone with constant isotope distributions, which creates extreme power rise at the beginning of the reactor operation. The optimized igniter structure considered in this paper has a more complex structure, which will be described further.

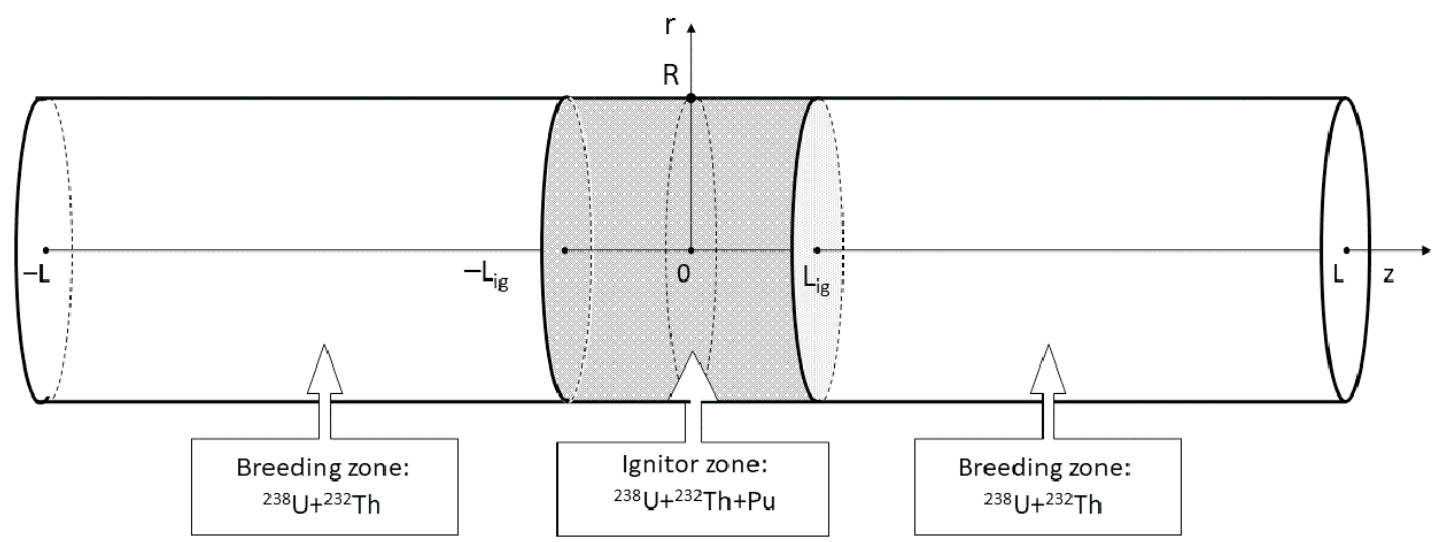

Fig.1. Initial critical assembly for the cylindrical FR with Th-U-Pu fuel cycle and the active ignition zone placed at the reactor center

The configuration of the FR is chosen to be nearly critical by solving the reactor criticality problem that determines size of the FR zones and the initial composition variants.

In the previous numerical simulations, the NBW was initiated by irradiating the ignition zone placed at one of the reactor ends by an external neutron flux $j_{e x}$ in the ignition zone. The source is placed in a certain cylinder section in the area with the largest enrichment, which in the case of the optimized structure will be near the boundary with the breeding zone, $z= \pm L_{i g}$.
The space-temporal NBW evolution in the FR has been simulated basing on the diffusion approach by solving the set of differential equations in partial derivatives, which consists of: the non-stationary diffusion equation of neutron transport, the fuelcomponent burn-up equations and the equations of nuclear kinetics of delayed neutron precursors. Radial zones with different isotope composition are not considered on the present stage. The influence of the radial neutron leakage is taken into account in the radial buckling approximation, which corresponds to the separation of variables. As a result, the radial 
neutron-flux distribution is described by the zeroorder Bessel function $\Phi^{g} \sim J_{0}\left(B_{r} r\right)$, where $B_{r}$ is the buckling coefficient [13]. This method is approximate for the NBW evolution simulation, because it neglects the radial non-uniformity of the fuel burn-up. In the case of the FR criticality problem for the initial assembly this method works exactly. The calculations performed in [9] for the exact two-dimensional cylindrical model of FR are in a good qualitative agreement with the analogous calculations in the buckling approximation, only small quantitative differences existing in characteristics of NBW (the critical FR radius, reactor's power and the velocity of NBW propagation).

The non-stationary problem of simulation of the NBW mode in the considered model is solved in the effective multi-group approach, which was developed by the authors in $[8,10,11]$. In this approach, the neutron flux evolution is described by the non-stationary effective one-group diffusion equation, which with taking into account delayed neutrons and using the radial buckling approximation, can be written as:

$$
\begin{aligned}
& \frac{1}{v} \frac{\partial \Phi}{\partial t}+\frac{\partial V}{\partial z}+D B_{r}^{2} \Phi+\Sigma_{a} \Phi-(1-\bar{\beta})\left(\nu_{f} \Sigma_{f}\right) \Phi \\
& =\sum_{l} \sum_{i} \lambda_{l}^{i}+Q(z, t) ; V=-D \frac{\partial \Phi}{\partial z} .
\end{aligned}
$$

Here $\Phi(z, t)$ is the scalar neutron flux, $\Sigma_{\alpha}(z, t)=$ $\sum_{j} \sigma_{\alpha}^{j}(z, t) N_{j}(z, t)$ are the macroscopic nuclear reactions cross-sections of the $\alpha$ type ( $\alpha=a, f$ corresponds to the absorption and fission reactions), $\sigma_{\alpha}^{j}(z, t)$ are the effective one-group microscopic crosssections of the $j$-th nuclide (in the effective multigroup approach they are dependent on the $z$ coordinate and time $t$ due to averaging them over the local neutron spectrum performed at each time layer); $N_{j}(z, t)$ is the $j^{t h}$ nuclide concentration at the point $z ; \quad D=1 /\left(3 \Sigma_{t r}\right)$ and $v$ are the onegroup diffusion coefficient and the neutron velocity, $\Sigma_{t r}$ is the macroscopic transport cross-section; $\bar{\beta}=\sum_{l} \beta_{l}\left(\nu_{f} \Sigma_{f}\right)_{l} / \sum_{l}\left(\nu_{f} \Sigma_{f}\right)_{l}$ is the effective delayed neutron fraction, beta $a_{l}=\sum_{i} \beta_{l}^{i}, \beta_{l}^{i}, C_{l}^{i}$ and $\lambda_{l}^{i}$ are the fractions of delayed neutrons, concentration and decay constants of precursor nuclei in the $i$-th group for the $l$-th fissile nucleus. The buckling coefficient equals $B_{r}=2.405 /\left(R+\delta_{r}\right)$, where the extrapolation length equal to $\delta_{r}=20 \mathrm{~cm}$, corresponds to the reflector economy for the case of a thick radial reflector of heavy material $(\mathrm{U}, \mathrm{Pb})[13]$. The function $Q(z, t)$ in the Eq. (1) describes the external neutron source, which is introduced for the purpose of NBW initiation in the FR.

The set of differential equations is solved taking into account the symmetry relative to the plane $z=0$, therefore only one half, with $0 \leq z \leq L$, of the reactor is considered. The boundary condition for the neutron flux in Eq. (1) at $z=0$ (the center of the reactor) is defined by the symmetry condition, and at the right boundary $(z=L)$ we have the condition for the free end:

$$
\left.\frac{\partial}{\partial z} \Phi(z, t)\right|_{z=0}=0,\left.(\Phi-2 V)\right|_{z=L}=0 .
$$

The first condition in Eq. (2) is different from the previously used condition $\left.(\Phi+2 V)\right|_{z=0}=2 j_{e x}$ for outer boundary irradiated by the flux $j_{e x}$. The initial flux distribution $\Phi(z, 0)$ on the interval $0 \leq z \leq L$ is taken in the form of a small-intensity flux for the initial critical assembly.

\section{RESULTS OF THE NBW SIMULATION}

The described model of the cylindrical FR with the fuel of Th-U-Pu cycle, operating in the NBW mode, and the proposed numerical calculation scheme are implemented in the original computer code FANTENS-B developed by the authors of this paper. It can be successfully used to simulate various transitional processes that take place during the reactor initial start-up, as well as the forced shutdown and restart, with a sufficient precision.
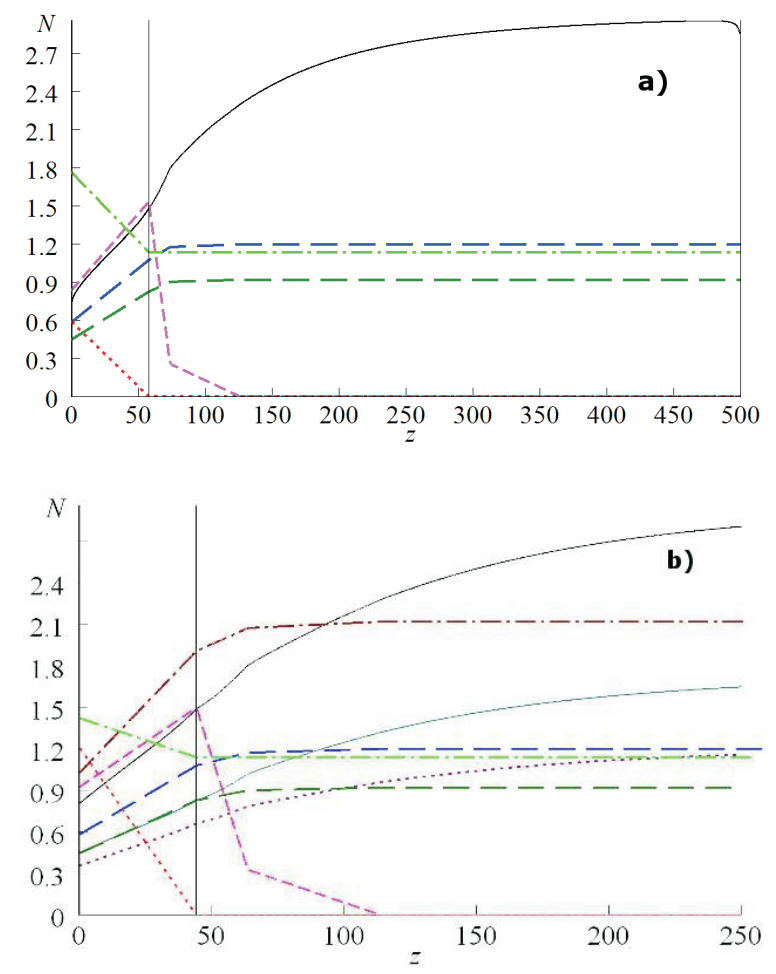

Fig.2. Initial optimized configurations of the FR with Th-U-Pu fuel for the cylinder-end start-up (a) and the center start-up (b). Concentrations of isotopes $N\left(10^{21} \mathrm{~cm}^{-3}\right)$ : for ${ }^{238} \mathrm{U}$ (top dashed), ${ }^{232}$ Th (bottom dashed), their sum (top dash-dotted), $\mathrm{Pb}$-Bi (bottom dash-dotted) and ${ }^{181} \mathrm{Ta}$ (dotted) are divided by 8; for ${ }^{239} \mathrm{Pu}$ (short dashes) and the effective equilibrium (solid line) for isotopes ${ }^{239} \mathrm{Pu}$ and ${ }^{233} \mathrm{U}$

The volume fractions of the components of the FR with metallic Th-U-Pu fuel and its geometrical parameters have been chosen based on the previous calculations $[11,12]$. The fuel fraction is $F_{\text {fuel }}=55 \%$, 
the construction material fraction is $F_{F e}=15 \%$, the $\mathrm{Pb}-\mathrm{Bi}$ coolant fraction is $F_{\text {cool }}=30 \%$, the volume fraction of the voids in the fuel is $20 \%$. The fuel in the breeding zone consists of $55 \%$ of ${ }^{232} \mathrm{Th}$ and $45 \%$ of ${ }^{238} U$ (the relative volume fractions), which ensures the NBW mode existence [10]. The basic geometric sizes of FR are length of the half-section $L=500 \mathrm{~cm}$ and the cylinder radius $R=173 \mathrm{~cm}$ (see Fig.1).
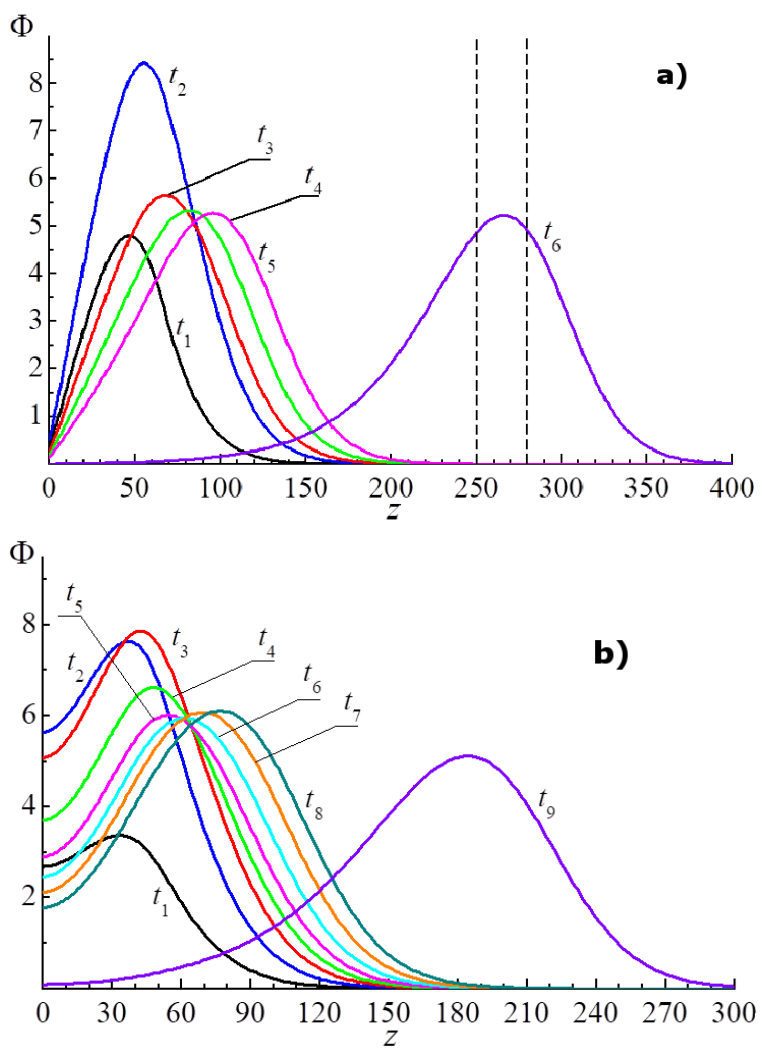

Fig.3. Initial stage of the $N B W$ evolution. Axial distributions of the neutron flux at different time moments. For the cylinder-end start-up (a): $t_{1}=200, t_{2}=1200, t_{3}=2200, t_{4}=3200, t_{5}=$ $4200, t_{6}=16425$ days. For the center startup (b): $t_{1}=400, t_{2}=900, t_{3}=1400, t_{4}=$ $1900, t_{5}=2400, t_{6}=900, t_{7}=3400, t_{8}=3900$ and $t_{9}=11500$ days

The initial FR compositions shown in Fig.2 have been chosen based on the solution of the critical parameter problem, so that the initial state is close to the critical one $\left(k_{e f f} \approx 1\right)$. The simulation of initiation and propagation of NBW in the FR was performed for both center and cylinder-end variants of the start-up. The results of the simulation are shown in Fig.3, where the evolution plots for the axial profiles of neutron flux for these two ignition method types are matched for comparison.

The initial FR configuration is chosen to have a small positive reactivity of $\rho \sim 10^{-3}$. With the help of the ${ }^{181} \mathrm{Ta}$ regulator the reactor is brought to subcritical state. For the cylinder-end start-up of FR, to bring the neutron field to the necessary level, a rather intensive external neutron flux of $\left(j_{\text {ex }} \approx 3.5 \cdot 10^{12} \mathrm{~cm}^{-2} \mathrm{~s}^{-1}\right)$ is required. To initiate the NBW mode in the reactor with the center startup, we use a bulk neutron source of a fairly small intensity $Q \approx 5 \cdot 10^{2} \mathrm{~cm}^{-3} \mathrm{~s}^{-1}$. This source was assumed to be placed in the layer $L_{i g}-\Delta_{q}<z<L_{i g}$, where $\Delta_{q}=10 \mathrm{~cm}$. Simultaneously with turning the neutron source on, the tantalum regulator is being slowly withdrawn from the active zone until the neutron field approaches NBW mode. The corresponding tantalum concentration is changed as $N_{T a}(t)=N_{T a}^{(0)}(T-t) / T$, where $N_{T a}^{(0)}=2.4 \cdot 10^{20} \mathrm{~cm}^{-3}$ and $T$ is the full withdrawal time of ${ }^{181} \mathrm{Ta}$ regulator. In the case of the cylinder-end start-up, the external neutron flux turn-off time is $T_{\text {off }}=500$ days and $T=180$ days. For FR with the center startup method, the bulk neutron source is turned off at $T_{\text {off }}=400$ days and $T=350$ days.
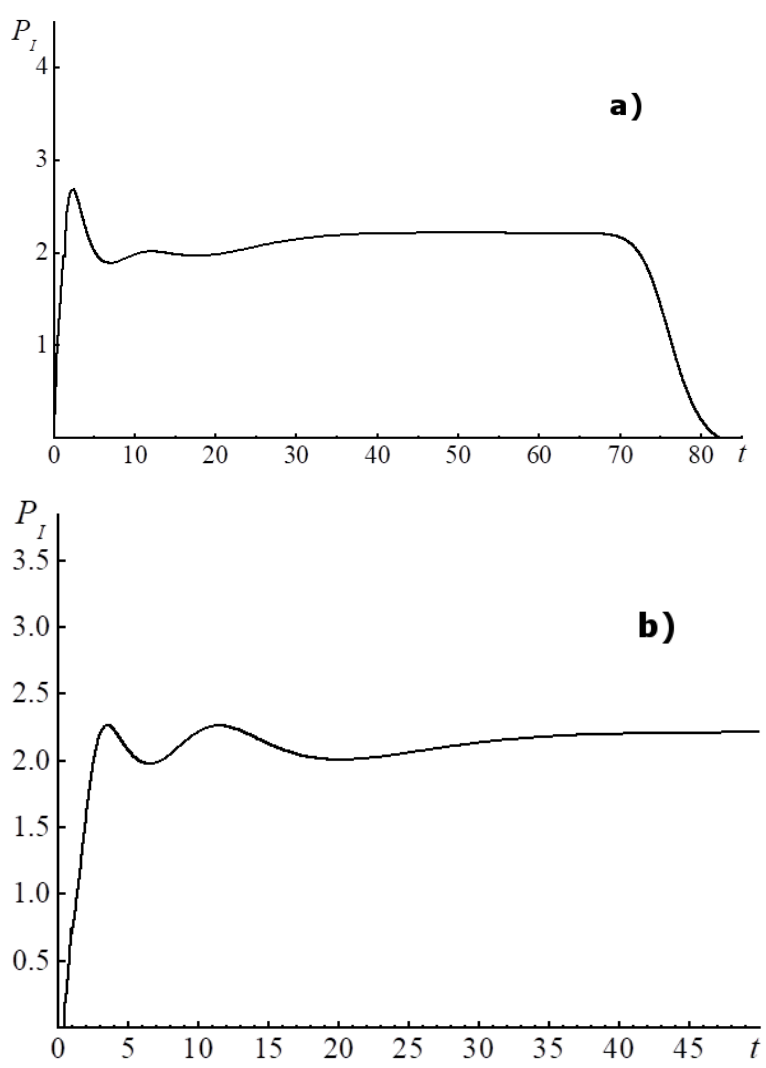

Fig.4. Integral power $P_{I}(G W)$ depending on time $t$ (years) (a) for the cylinder-end start-up and (b) for the center start-up (over the half FR section $0<z<L$ )

The temporal distributions of the reactor power production of the considered section of FR $(0<z<L)$, are shown in Fig.4,a,b. At the beginning of operation of the both considered variants of FR, the FR power varies in range of $\pm 10 \%$, as compared with its steady state value, and afterwards the reactors approach the stationary NBW mode. It should be mentioned, that the optimized ignition zone prevents the above-mentioned high rise of power production at the beginning (which can reach up to 20 times, see [12]). The characteristic NBW velocity in this 
case is $5.2 \mathrm{~cm} /$ year with the reactor campaign duration about 70 years. For both considered reactor configurations (the center and cylinder-end start-up variants) the power production for the section $0<z<L$ in the stationary NBW mode is about $2.2 \mathrm{GW}$.

Starting the reactor from its center means no axial neutron leakage at $z=0$, thus a less amount of the fissile material per unit of power is required in the ignition zone. For the cylinder-end start-up, 1.7 ton $/ G W$ of ${ }^{239} \mathrm{Pu}$ is required in the ignition zone, and for the center start-up of the reactor it is it is 1.5 ton $/ G W$.

\section{CONCLUSIONS}

The prospective fast reactor with the $\mathrm{Th}-\mathrm{U}-\mathrm{Pu}$ fuel cycle operating in the nuclear burning wave mode with the initial enriched ignition zone in the center of the reactor core with cylindrical geometry has been considered, the NBW propagating along the cylinder axis in both directions from the center. The study of the processes in the reactor has been performed by means of numerical calculations using the set of computer programs developed by the authors. The model implemented in the computer programs uses the deterministic approach based on solving the diffusion neutron transport equation, fuel burn-up equations, and kinetic equations for precursor nuclei of delayed neutrons. The calculations have been performed in the multi-group approach with the use of buckling approximation.

The optimized ignition zone that prevents excessive rise of the FR power at the start-up stage is proposed. In the considered scenario the NBW mode is initiated by bringing the neutron flux to the required level by means of low-intensity external bulk neutron source and a tantalum absorbing regulator. The processes occurring at the reactor start-up have been studied in detail.

The results obtained in the work have been compared to the calculations for the reactor that is started up by an external neutron flux irradiating the cylinder end. The comparison shows a certain reduction of the required plutonium amount per unit of power output. The bulk neutron source required for the FR start-up can be of by far more feasible intensity than the external neutron flux for the cylinderend start-up. It should be mentioned, that the reactor with the center start-up initiates two nuclear burning waves simultaneously, which produce twice as much power.

\section{References}

1. L.P. Feoktistov. Analysis of a concept of physically safe reactor. Preprint: IAE-4605/4. M.: IAE, 1988, 4 p. (in Russian).
2. L.P. Feoktistov. Neutron-fissioning wave // Dokl.Akad. Nauk USSR. 1989, v.309, p.864-867 (in Russian).

3. V.Ya. Goldin, D.Yu. Anistratov. Fast neutron reactor in a self-adjusting neutron-nuclide regime // Mathematical Modelling. 1995, v.7, p.12-32 (in Russian).

4. H. Van Dam Self-stabilizing criticality waves // Annals of Nuclear Energy. 2000, v.27, p.15051521.

5. E. Teller. Nuclear Energy for the Third Millennium. Preprint UCRL-JC-129547, LLNL, Livermore, CA, USA, 1997.

6. H. Sekimoto. Light of CANDLE. New Burnup Strategy. Tokyo Institute of Technology, 2005, $47 \mathrm{p}$.

7. S.P. Fomin, Yu.P.Mel'nik, V.V.Pilipenko, N.F. Shul'ga. Investigation of Self-Organization of the Non-Linear Nuclear Burning Regime in Fast Neutron Reactors // Annals of Nuclear Energy. 2005, v.32, p.1435-1456.

8. S.P. Fomin, Yu.P. Mel'nik, V.V.Pilipenko, N.F. Shul'ga. Initiation and Propagation of $\mathrm{Nu}-$ clear Burning Wave in Fast Reactor // Progress in Nuclear Energy. 2008, v.50, p.163-169.

9. S.P.Fomin, A.S. Fomin, Yu.P. Melnik, V.V.Pilipenko, N.F.Shul'ga. Safe Fast Reactor Based on the Self-Sustained Regime of Nuclear Burning Wave // Proc. of First Intern. Conf. "Global 2009". Paper 9456, Paris, France, 2009, 9p.

10. S.P. Fomin, O.S. Fomin, Yu.P.Mel'nik, V.V.Pilipenko, N.F.Shul'ga. Nuclear burning wave in fast reactor with mixed Th- $\mathrm{U}$ fuel // Progress in Nuclear Energy. 2011, v.53, p.800-805.

11. O.S. Fomin, S.P. Fomin, Yu.P. Mel'nik, V.V.Pilipenko, N.F.Shul'ga. Nuclear burning wave reactor: smooth start-up problem // Journal of Kharkiv Nat. Univ. Phys. ser: "Nuclei, Particles, Fields", 2013, N1041, issue 2 /58/, p.49-56.

12. O.S. Fomin, S.P.Fomin, Yu.P. Melnik, V.V.Pilipenko, N.F.Shul'ga. Transient Processes in the Nuclear-Burning-Wave Reactor // Proc. of Intern. Conf. "Global 2015". Paper 5254, Paris, France, 2015, 9p.

13. A.E. Waltar, A.B. Reynolds. Fast Breeder Reactors. New York: "Pergamon Press", 1981, 605p. 


\title{
ОПТИМИЗАЦИЯ ЗОНЫ ЗАПАЛА ПЕРСПЕКТИВНОГО БЫСТРОГО РЕАКТОРА, РАБОТАЮЩЕГО В РЕЖИМЕ ВОЛНЫ ЯДЕРНОГО ГОРЕНИЯ
}

\author{
С. П. Фомин, А.И. Кирдин, М. С. Маловича, В. В. Пилипенко, Н. Ф. Шулъга
}

Изучается вопрос оптимизации состава и структуры зоны запала быстрого реактора, работающего в самоподдерживающемся режиме волны ядерного горения, с целью его плавного запуска и экономии делящихся материалов на эом этапе. Рассматривался гомогенный реактор цилиндрической формы с центральным либо торцевым расположением зоной запала. Анализ проводился на основе численного решения нестационарного уравнения диффузии нейтронов вместе с уравнениями выгорания и уравнениями кинетики ядер предшественников запаздывающих нейтронов. Задача решалась с использованием приближения геометрического фактора баклинга. Предложена оптимизированная структура зоны запала, обеспечивающая плавный выход реактора на стационарный самоподдерживающийся режим волны ядерного горения, избегая значительного роста энерговыделения, который наблюдается при использовании упрощенной схемы зоны запала. Проведено сравнение количества делящегося материала, необходимого для запуска реактора, при двух вариантах расположения зоны запала: торцевой и центральной.

\section{ОПТИМИЗАЦІЯ ЗОНИ ЗАПАЛУ ПЕРСПЕКТИВНОГО ШВИДКОГО РЕАКТОРА, ЯКИЙ ПРАЦЮЕ В РЕЖИМІ ХВИЛІ ЯДЕРНОГО ГОРІННЯ}

\section{С. П. Фомін, А. И. Кирдин, М. С. Маловичя, В. В. Пилипенко, М. Ф. Шулъга}

Вивчається питання оптимізації складу та структури зони запалу швидкогоого реактора, працюючого в режимі самопідтримки хвилі ядерного горіння, з метою його плавного запуску та економії материалів, які діляться на цьому етапі. Розглядався гомогенний реактор ціліндричної форми з центральним або торцевим розміщенням зони запалу. Аналіз проводився на основі числового рішения нестаціонарного рівняння диффузії нейтронів разом з рівняннями вигорання і рівняннями кінетики ядер попередників запізнілих нейтронів. Задача вирішувалась з використанням наближення геометричного фактора баклінга. Запропонована оптимізована структура зони запалу, яка забезпечує плавний вихід ректора на стаціонарний режим хвилі ядерного горіння, яка само підтримується, уникаючи значного росту енерговиділення, яке спостерігається при використанні спрощеної схеми зони запалу. Проведено порівняння кількості материалу, який ділеться, необхідної для запуску реактора, при двух варіантах розташування зони запалу: торцевої та центральної. 